\title{
Toward a new information infrastructure in health technology assessment: Communication, design, process, and results
}

\author{
Susanna Allgurin Neikter \\ Swedish Council on Technology Assessment in Health Care \\ Nina Rehnqvist \\ Swedish Council on Technology Assessment in Health Care and Karolinska Institute \\ Måns Rosén \\ Swedish Council on Technology Assessment in Health Care and Umeå University \\ Helena Dahlgren \\ Swedish Council on Technology Assessment in Health Care
}

Objectives: The aim of this study was to facilitate effective internal and external communication of an international network and to explore how to support communication and work processes in health technology assessment (HTA).

Structure and Methods: European network for Health Technology Assessment (EUnetHTA) connected sixty-four HTA Partner organizations from thirty-three countries. User needs in the different steps of the HTA process were the starting point for developing an information system. A step-wise, interdisciplinary, creative approach was used in developing practical tools.

Results: An Information Platform facilitated the exchange of scientific information between Partners and with external target groups. More than 200 virtual meetings were set up during the project using an e-meeting tool. A Clearinghouse prototype was developed with the intent to offering a single point of access to HTA relevant information. This evolved into a next step not planned from the outset: Developing a running HTA Information System including several Web-based tools to support communication and daily HTA processes. A communication strategy guided the communication effort, focusing on practical tools, creating added value, involving stakeholders, and avoiding duplication of effort.

Conclusions: Modern technology enables a new information infrastructure for HTA. The potential of information and communication technology was used as a strategic tool.

Several target groups were represented among the Partners, which supported collaboration and made it easier to identify user needs. A distinctive visual identity made it easier to gain and maintain visibility on a limited budget.

Keywords: Health Technology Assessment, Europe, Information system, Communication, Design, EUnetHTA 
The rapid developments in information and communication technology together with the growth of the European Union offer new opportunities for collaboration across borders. EUnetHTA (European network for Health Technology Assessment) is an open network connecting organizations with each other and developing practical tools to facilitate crossborder collaboration and to avoid duplication of efforts. The EUnetHTA Project is described in two separate articles $(11 ; 12)$. The Communication Work Package, in collaboration with the EUnetHTA Secretariat, was responsible for the external communication, as well as the internal communication between more than 300 individuals from sixty-four organizations in thirty-three countries.

\section{OBJECTIVES AND AIMS}

\section{Communication Objectives}

The communication objectives were twofold: to facilitate coherent and effective internal and external communication of the project and to explore how to support communication and work processes in HTA.

\section{Aims}

The aims were as follows: To develop and implement a communication strategy; To develop a logotype, graphic profile, and information package; To develop an Information Platform; To develop a prototype of a Clearinghouse; and To develop a running HTA Information System (added aim during the process).

\section{STRUCTURE AND METHODS}

\section{Theoretical Background}

Communication is a multidisciplinary field involving several approaches. The nature of marketing has changed in recent decades, from selling and delivering products, to include developing and maintaining mutually satisfying long-term relationships (5). The modern approach views marketing as effective human communication in its widest sense (13).

Relationship marketing and knowledge management are two young academic disciplines with many similarities. $R e$ lationship marketing includes relationships, networks, and interaction based on information technology (9). Collaboration is central, and knowledge is the prime reason for alliances. Knowledge management involves the identification and use of knowledge to improve decisions and actions (25). Knowledge is viewed as a resource for an organization's success.

Design management forms the theoretical approach for the design aspect. The logotype and graphic profile can be described as the visual statement to the world of who and what the organization is, and how the organization views itself (17). Visual identity strengthens the sense of belonging and must reflect the organization and its objectives. A symbol makes it easier to gain recognition and to recall. Symbols are most powerful if they involve a visual metaphor (1).

An unmet need can be strategically important as it offers new opportunities. However, individuals are not always aware of their needs because they are accustomed to the existing limitations. The key is to develop the technology, or apply new technology, to expose unmet needs (1). Creativity can be viewed as a function of knowledge, evaluation, and imagination. It can also be a way to reorganize experience into new configurations (10). A network in itself has a structure that promotes creativity (4). Creativity could be the key to achieving competitive advantages, which is also supported by research.

\section{Communication Group}

The Partners of the Communication Work Package came from different countries with different languages, cultures, and healthcare systems. The individual members involved represented different professional backgrounds, for example, HTA, medicine, health economics, information science, project management, and communication. The group also included representatives from the other Work Packages $(11 ; 12)$. The Communication Work Package, led by SBU in Sweden, was responsible for internal and external communication in collaboration with the EUnetHTA Secretariat. The Clearinghouse subgroup, led by DAHTA/DIMDI in Germany, was responsible for the Clearinghouse project.

\section{Methodology}

Development of the EUnetHTA Information Platform, and later the HTA Information System followed an iterative model (15). The project used a practical, interdisciplinary and creative approach. Members' needs were the starting point for the development process. A test site was set up to enable members to follow the development, try out the tools, and to submit comments. Members described their problems and needs, during meetings, group discussions, and informal interviews - and EUnetHTA tried to solve them. Different steps in the HTA process were identified. Each step involved discussing tools that would be useful to support collaboration, speed up the HTA process, and enhance quality. New ideas and technical solutions were also added.

\section{Technology}

Electronic channels, for example, e-meetings, e-newsletters, e-mails, and the Web site, were the most common means of communication. A virtual e-meeting tool (www.saba.com/ products/centra/) was provided to EUnetHTA Partners during the project.

A CMS (content management system) was used as a basic technical framework for the Information Platform, and enabled members to update information on the Web site regardless of programming skills. The chosen CMS, EpiServer (www.episerver.com), included several sets of functions to 
choose from and adapt to the Web site. An effort was made to develop functions that could be used in different Web-based tools. As there was a limited budget, the aim was to be selfsustained and able to develop the Web site further without help from computer programmers. For example, instead of setting up a specific database, a database tool was developed that would enable us to set up several databases ourselves. Another strategy was to develop Web-based tools that were as automated as possible, for example, to include automatic reminders when information is not updated.

\section{RESULTS}

\section{Communication Strategy}

A communication strategy was developed to guide the communication effort (3). A key component of the strategy was to focus on collaboration with Network Partners and other relevant external target groups and stakeholders. Guiding principles included focusing on practical tools, creating added value, involving stakeholders, and avoiding duplication of effort.

Counterforces facing EUnetHTA were identified early in the project and were addressed in the communication strategy. EUnetHTA clarified that the intent was to cooperate with established international HTA organizations and that the focus of communication was on the European level. EUnetHTA should not interfere with decisions made by other network organizations, and it was made clear that the communication and decision making on the national and regional levels were left to the Partners. Two supporting documents were developed: Publication Guidelines (21) and Graphic Guide (2).

Network Partners were prioritized as a target group and were viewed as an important channel to reach and influence a wider range of people and organizations, as each Partner had their own network of contacts in the HTA field. Partners were encouraged to actively participate in the communication effort and were responsible for communication on the national and regional levels. EUnetHTA, on the other hand, served as a channel for the Partners to promote themselves at the European level. Another important factor was that EUnetHTA Partners represented the prioritized target groups. This gave EUnetHTA an opportunity to reach and collaborate closely with many key target audiences.

\section{Visual Identity}

Early in the project, EUnetHTA was given a distinct visual identity with a graphic profile and a logotype to make the project stand out and become visible and recognized (2). Identity found expression in the distinct name, logotype, symbols, fonts, imagery, and colors. The logotype, a visual metaphor, suggests a network and the sun projecting energy. The logotype tells a story through its symbolic meaning and hidden message-HTA. An information package was de- veloped to support Partners' communication on behalf of EUnetHTA.

\section{Information Platform}

The EUnetHTA Information Platform included a public Web site (www.eunethta.net) with a members-only area and eight extranets, one for each working group. The Web site included some communication support tools, for example, calendar, news feed, discussion forums, voting function, group mail, form templates, etc. The Information Platform was developed and hosted by the Work Package Lead Partner (SBU) with input from Partners and content development and provision by the EUnetHTA Secretariat. During 2008, there were 89,646 unique visitors to the Web site.

EUnetHTA used electronic channels and modern technology to facilitate effective communication within the network and to external users. Between face-to-face meetings, more than 200 virtual e-meetings were organized during the project. The e-meeting tool included several functions, for example, document sharing, audio conferencing, text chat, and a possibility to vote.

\section{Clearinghouse Prototype}

The Clearinghouse report, prepared by the Co-Lead Partner DAHTA/DIMDI and a smaller subgroup (7), described the future Clearinghouse as a technical system offering a single point of access to all HTA-relevant information, for example, HTA reports, databases, and different tools. A computer interface for demonstration was also set up. The Clearinghouse should facilitate communication and sharing of high-quality information in the HTA community. It should also reduce duplication of effort by connecting to existing information and databases. One challenge was to define and describe the terminology needed to achieve common understanding. The prototype also described technical options regarding tools to be developed in other Work Packages.

The Clearinghouse report was evaluated by Partner Organizations in the EUnetHTA Executive Committee (16). The Partners decided not to endorse further development of the suggested solution for the Clearinghouse as it was described in the prototype. The full-scale Clearinghouse would have required a major investment of resources. Instead, a smallscale approach was chosen: to further develop the Web site already in place as the starting point of a HTA Information System. It was also decided that each Work Package Lead Partner should continue to develop and host its own Webbased tools, for example, the HTA Core Model (14) and the Adaptation Toolkit (23). The project aim had been to develop a prototype of a Clearinghouse-not an operating Clearinghouse. This task was accomplished and taken one step further by starting a new project, not planned from the outset-to develop a running HTA Information System. 


\section{HTA Information System}

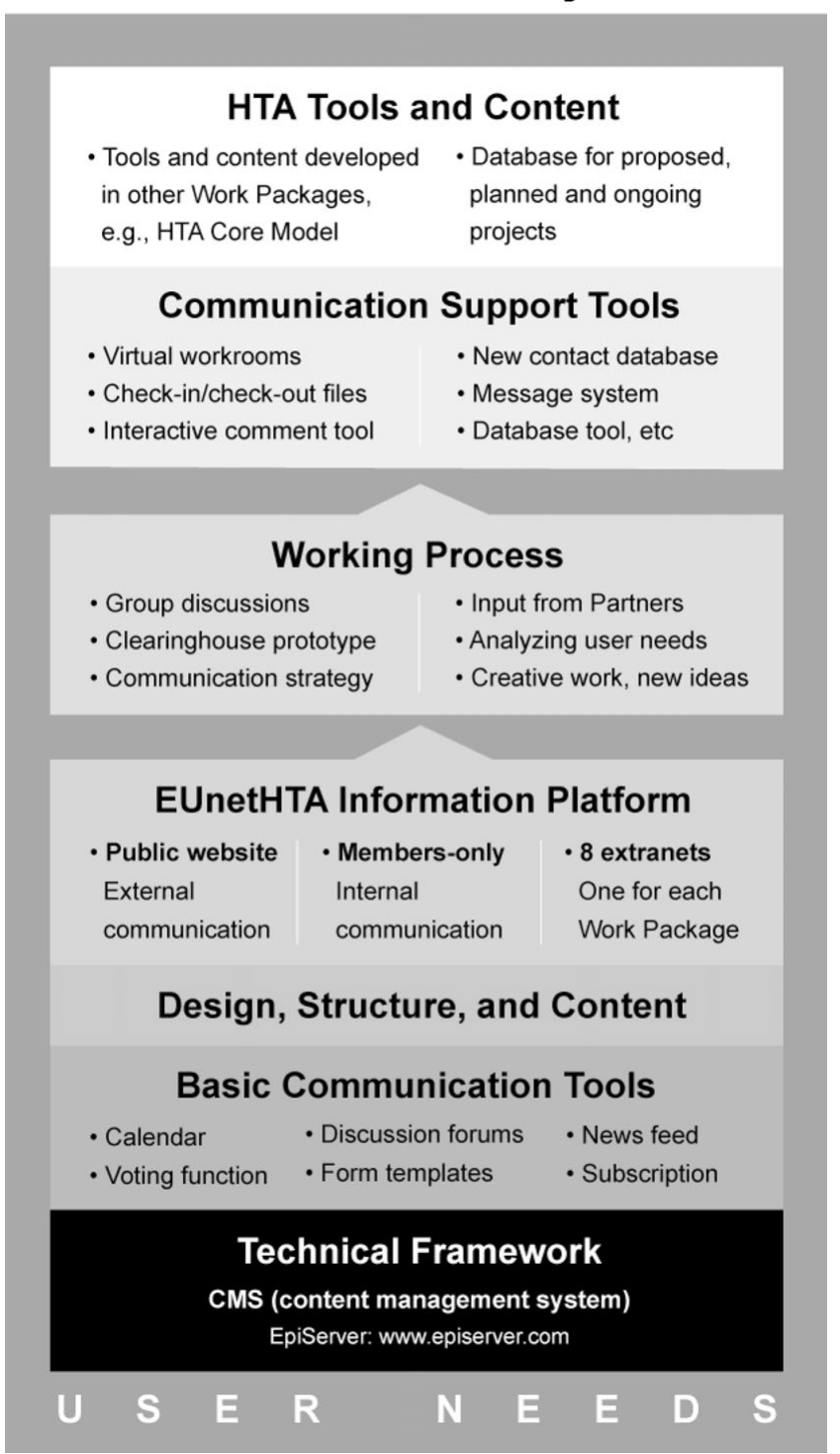

Figure 1. Process to develop the European network for Health Technology Assessment (EUnetHTA) health technology assessment (HTA) Information System.

\section{HTA Information System}

SBU developed the HTA Information System starting from the existing Web site (Figure 1). New information, functions, and tools were added to the Web site, with a focus on developing a user-friendly system that met the Partners' needs. An overview of the HTA Information System is given in Table 1. Previous group discussions, the Clearinghouse prototype (7), the Communication strategy (3), and a list of prioritized functions desired by Network Partners (8) guided the process. An important guiding principle in the Communication Strategy was to avoid duplication of effort. Therefore, some requests relevant to the improvement of the HTA
Database were forwarded to the International Network of Agencies for Health Technology Assessment (INAHTA).

\section{DISCUSSION}

Information and communication technology has changed the way we work, providing many opportunities. EUnetHTA took advantage of the new technology and adapted it to the HTA context. Likewise, modern technologies will give other HTA organizations new opportunities to develop technical solutions, which will further change the way we work in the HTA community. How EUnetHTA was organized-as an open transparent network - was important, as the network construction is known to promote communication, ideas, and creativity.

\section{Communication Strategy}

Network Partners were identified as the most important target group and also as a communication channel. Hence, an important aspect was the partnership pool. EUnetHTA Partners represented a majority of the important HTA organizations, HTA networks, and other key organizations. One could say that communication started already when the Network Partners were recruited.

\section{Information Platform}

An observation made early in the project, supported by some research (6), was that many HTA doers are not used to new information and communication technology. Initially, many individuals were hesitant to work with new functions; however, throughout the project they became more accustomed to using the communication tools. The extranet editors attended a training course to learn to edit the extranets. Even so, the Webmaster and Secretariat developed and published most of the content. One hurdle was the technical requirements for editors that demanded PC (not, e.g., Macintosh) and the Web-browser Internet Explorer. Another hurdle was to encourage individuals to change habit and invest time to learn a new system, not used daily. In the future, as more people become editors, they should be provided with more support and gradually trained to take on responsibility.

\section{Clearinghouse Prototype}

The Clearinghouse project was a large effort that tried to cover many different aspects of the HTA process (7). As the prototype covered so much, it was difficult to overview the concept. During the project time frame, it was difficult to explain and later promote the advantages of the Clearinghouse prototype. Members found it difficult to understand the Clearinghouse document, as it was thought to be overly technical and theoretical. In addition, the word "prototype" meant different things to different people. Some expected a system instead of a document. There was also a language 
Allgurin Neikter et al.

Table 1. HTA Information System: Overview of Structure, Web-Based Tools and Functions

\begin{tabular}{|c|c|c|}
\hline Content & Functions and tools & User needs/problem solved \\
\hline \multirow[t]{3}{*}{ The EUnetHTA Web site } & Public Web site & $\begin{array}{l}\text { External communication with different } \\
\text { target groups and stakeholders }\end{array}$ \\
\hline & Members-only site & Internal communication \\
\hline & 8 extranets & Communication within each working group \\
\hline $\begin{array}{l}\text { Contact database of individual } \\
\text { members, organizations, } \\
\text { experts, and working groups }\end{array}$ & $\begin{array}{l}\text { Each member can update information and } \\
\text { upload images and documents. Connection } \\
\text { to e-mail and message system (inspired by } \\
\text { the social networking tool Facebook }{ }^{\mathrm{TM}} \text { ) }\end{array}$ & $\begin{array}{l}\text { To collaborate and to find experts with } \\
\text { special backgrounds and knowledge. } \\
\text { Possibility to get lists in spreadsheet } \\
\text { format }\end{array}$ \\
\hline $\begin{array}{l}\text { Database for proposed, planned } \\
\text { and ongoing projects }\end{array}$ & $\begin{array}{l}\text { Each member can submit and edit } \\
\text { information about projects. If the } \\
\text { information is not updated an automatic } \\
\text { reminder will be sent }\end{array}$ & $\begin{array}{l}\text { To avoid duplication of effort and to } \\
\text { collaborate early in the HTA process }\end{array}$ \\
\hline \multirow[t]{9}{*}{$\begin{array}{l}\text { Communication tools } \\
\text { (examples) }\end{array}$} & $\begin{array}{l}\text { Virtual workrooms including interactive } \\
\text { notice board }\end{array}$ & $\begin{array}{l}\text { To facilitate working together, e.g., share } \\
\text { information and documents, upload } \\
\text { images, participate in discussions }\end{array}$ \\
\hline & $\begin{array}{l}\text { Check-in/check-out files directly on the } \\
\text { Web site }\end{array}$ & $\begin{array}{l}\text { To upload and down load documents and } \\
\text { pictures }\end{array}$ \\
\hline & e-newsletter function & To send many e-newsletters at the same time \\
\hline & Discussion forums & $\begin{array}{l}\text { To discuss different topics and be able to } \\
\text { follow the threads in the discussion }\end{array}$ \\
\hline & Search engine & To find relevant information \\
\hline & $\begin{array}{l}\text { Database tool, voting tool, survey tool, and } \\
\text { appraisal tool (draft) }\end{array}$ & $\begin{array}{l}\text { To set up a database, to vote, to make a } \\
\text { survey, and to support the appraisal } \\
\text { process }\end{array}$ \\
\hline & Interactive tool to submit comments & $\begin{array}{l}\text { To be able to make comments directly on the } \\
\text { Web site }\end{array}$ \\
\hline & Message system (an alternative to e-mail) & $\begin{array}{l}\text { To be able to send short messages to other } \\
\text { members directly from the Contact } \\
\text { database }\end{array}$ \\
\hline & Subscription on automatic updates & $\begin{array}{l}\text { To be alerted when new information is } \\
\text { published on the Web site by e-mail. A } \\
\text { possibility to choose frequency of the } \\
\text { updates }\end{array}$ \\
\hline Personalization of the Web site & $\begin{array}{l}\text { Different members can be given different } \\
\text { access rights, e.g., to edit information, } \\
\text { enter virtual workrooms, and start their } \\
\text { own working groups. Members-only is } \\
\text { adapted to each individual with name, } \\
\text { photo, contacts, links, etc. }\end{array}$ & $\begin{array}{l}\text { To enable tailor-made information and } \\
\text { services according to individual interests } \\
\text { and needs }\end{array}$ \\
\hline $\begin{array}{l}\text { Information developed in other } \\
\text { Work Packages }\end{array}$ & $\begin{array}{l}\text { EUnetHTA and European Observatory book } \\
\text { on HTA and policy making (24) } \\
\text { EUnetHTA Handbook on HTA Capacity } \\
\text { Building (18) }\end{array}$ & $\begin{array}{l}\text { To connect HTA and policy making in } \\
\text { Europe } \\
\text { To support HTA in countries with limited } \\
\text { institutionalization of HTA }\end{array}$ \\
\hline \multirow[t]{4}{*}{$\begin{array}{l}\text { Tools developed in other } \\
\text { Work Packages }\end{array}$} & $\begin{array}{l}\text { Open stakeholder forum, dedicated part of } \\
\text { Web site (19) } \\
\text { HTA Core model }\end{array}$ & $\begin{array}{l}\text { To support communication with stakeholders } \\
\text { on the European level } \\
\text { To develop a common methodology for HTA } \\
\text { to support collaboration and sharing of } \\
\text { results }\end{array}$ \\
\hline & $\begin{array}{l}\text { Web-based toolkit for adapting core HTA } \\
\text { results }(23)\end{array}$ & $\begin{array}{l}\text { To facilitate the local adaptation and use of } \\
\text { HTA in Europe }\end{array}$ \\
\hline & Glossary of HTA adaptation terms (22) & To enhance understanding \\
\hline & $\begin{array}{l}\text { Set of tools for monitoring new emerging } \\
\text { technologies (20) }\end{array}$ & $\begin{array}{l}\text { To provide tools to monitor the development } \\
\text { of health technologies and to provide } \\
\text { information on new and emerging } \\
\text { technologies }\end{array}$ \\
\hline
\end{tabular}


problem, both when using English as a second language, but also when using technical terms that people from an HTA background did not understand.

\section{HTA Information System and Working Process}

A user-friendly interface was prioritized when building the new HTA Information System, to make it easy for HTA doers to use the tool, actively contribute with content, and eventually become editors. Focusing only on meeting user needs would have been insufficient, as members cannot request functions that they may not know exist. The relationship between needs and creative problem solving is twofold. New ideas and possibilities can also generate new user needs. The project was taken a step further by addressing new ideas. Had it focused only on meeting the limited specific needs expressed by the Partners, the innovative character of the project would have been less.

Research confirms that commitment and trust are important for knowledge exchange in a network. In an HTA context, this suggests that it is important for HTA agencies to trust each other to be able to use each other's information. In a long-term relationship, the parties adapt to one another (13). If that happens, it will become easier to work together and to use each other's reports and results in the future.

The HTA Information System can be described as an innovation, at least in the HTA context. The ability to implement and continuously develop the system and the tools will be essential to the Network's future success.

\section{CONCLUSIONS}

The EUnetHTA project developed an HTA Information System that included tools for communication and HTA processes. The aim was to support cross-border collaboration to avoid duplication of work among HTA agencies in Europe. The work focused on building structures and practical tools, providing real added value for the Partners.

EUnetHTA took advantage of contemporary technical opportunities to promote innovation in the HTA community and used modern technology as a strategic tool.

Modern information and communication technology supported the network development and collaboration between members. The EUnetHTA HTA Information System, along with technical solutions and Web-based tools developed in other HTA organizations, will offer a new information infrastructure for HTA and could change the way we work in the future.

The communication strategy guided the communication activities in the Network. As collaboration was a guiding principle, it was important that many target groups also were involved in EUnetHTA. This made it easier to collaborate closely and identify user needs.
Design was used as a strategic tool and was identified as a means to achieve and maintain visibility on a limited budget. EUnetHTA's clear visual identity helped the project to stand out from other projects.

\section{CONTACT INFORMATION}

Susanna Allgurin Neikter (allgurin@sbu.se), Marketing Director, Swedish Council on Technology Assessment in Health Care (SBU), Olof Palmes Gata 17, P.O. Box 3657, SE-103 59 Stockholm, Sweden

Nina Rehnqvist, MD, PhD (rehnqvist@sbu.se), Chairperson, Swedish Council on Technology Assessment in Health Care, P.O. Box 3657, SE-103 59 Stockholm, Sweden; Adjunct Professor, Department of Medicine, Karolinska Institute, SE-171 76 Stockholm, Sweden

Måns Rosén, PhD (rosen@ @bu.se), Director, Swedish Council on Technology Assessment in Health Care, P.O. Box 3657, SE-103 59 Stockholm, Sweden; Adjunct Professor, Epidemiology and Public Health, Umeå University, SE-901 85 Umeå, Sweden

Helena Dahlgren, MBA (dahlgren@ @bu.se), Deputy Director, Swedish Council on Technology Assessment in Health Care, P.O. Box 3657, SE-103 59 Stockholm, Sweden

\section{REFERENCES}

1. Aaker DA. Strategic market management. New York: John Wiley \& Sons, Inc; 1998.

2. Allgurin Neikter S. EUnetHTA graphic guide. Internal document. EUnetHTA; 2006.

3. Allgurin Neikter S, Rehnqvist N, et al. EUnetHTA communication strategy 2006-2008. Internal document. EUnetHTA; 2007.

4. Brown JS, Duguid P. Creativity versus structure: A useful tension. Manag Technol Innov. 2001;42:93-94.

5. Buttle F. Relationship marketing. Theory and practice. London: Paul Chapman Publishing Ltd; 1996.

6. Chalon P, Di Pretoro E, Kohn L. OPAC 2.0: Opportunities, development and analysis. In 11th European Conference of Medical and Health Libraries, Helsinki (Finland), 23rd-28th of June 2008. Available at: http://eprints.rclis.org/14372/. Accessed February 10, 2009.

7. Dauben H-P, Rüther A, Christofides S, et al. The Clearinghouse prototype. EUnetHTA; 2008. Available at: http://www. eunethta.net/Public/EUnetHTA_Deliverables_project_20062008/. Accessed October 28, 2008.

8. EUnetHTA. Proposal for the EUnetHTA Collaboration. June 16, 2008. Available at: http://www.eunethta.net/Public/ EUnetHTA_Deliverables_project_2006-2008/. Accessed October 28, 2008.

9. Gummesson E. Relationsmarknadsföring: Från 4P till 30R. Malmö: Liber; 2006.

10. Kreitner R. Management. Boston: Houghton Mifflin Company; 1986.

11. Kristensen FB, Lampe K, Chase DL, et al. Practical tools and methods for health technology assessment in Europe: Structures, methodologies, and tools developed by the European 
network for Health Technology Assessment, EUnetHTA. Int J Technol Assess Health Care. 2009;25(Suppl 2):1-8.

12. Kristensen FB, Mäkelä M, Allgurin Neikter S, et al. European network for Health Technology Assessment, EUnetHTA: Planning, development, and implementation of a sustainable European network for Health Technology Assessment. Int J Technol Assess Health Care. 2009;25(Suppl 2):107-116.

13. Lagrosen S, Svensson G, eds. Marketing: Broadening the horizons. Lund, Sweden: Studentlitteratur; 2006.

14. Lampe K, Mäkelä M, Velasco-Garrido, etc. The HTA Core Model: A novel method for producing and reporting health technology assessments. Int J Technol Assess Health Care. 2009;25(Suppl 2):9-20.

15. Larman C. Agile and iterative development: A manager's guide. Agile Software Development Series. Boston: Pearson Education, Inc; 2004.

16. Lund Håheim L, Røttingen J-A, Mørland B. Norwegian knowledge centre for the health service evaluation report of the Clearinghouse strand of Work Package 2. Internal document. EUnetHTA; 2008.

17. Melewar TC, Basset K, Simoes C. The role of communication and visual identity in modern organizations. Corporate Communications: An International J. 2006;11:138-147.

18. Moharra M. EUnetHTA handbook on HTA capacity building. EUnetHTA; 2008. Available at: http://www.eunethta. net/Public/EUnetHTA_Deliverables_project_2006-2008/. Accessed February 10, 2009.

19. Palmhøj Nielsen C, Wadmann Lauritsen S, Kristensen FB, et al.
Involving stakeholders and developing a policy for stakeholder involvement in the European network for Health Technology Assessment, EUnetHTA. Int J Technol Assess Health Care. 2009;25(Suppl 2):84-91.

20. Quentin F, Carbonneil C, Moty-Monnereau C, et al. Web-based toolkit to facilitate European collaboration on evidence generation on promising health technologies. Int J Technol Assess Health Care. 2009;25(Suppl 2):68-74.

21. Rehnqvist N, Kristensen FB. EUnetHTA Publication Guidelines. Principles on publications, presentations, and other public communication in EUnetHTA. EUnetHTA; 2006. Available at: http://www.eunethta.net/Public/Communication. Accessed December 3, 2008.

22. Rosten C, Chase DL, Hicks NJ, Milne R. Enhancing understanding: The development of a glossary of health technology assessment adaptation terms. Int J Technol Assess Health Care. 2009;25(Suppl 2):42-47.

23. Turner S, Chase DL, Milne R, et al. The adaptation of health technology assessment reports: Identification of the need for, and development of, a toolkit to aid the process. Int J Technol Assess Health Care. 2009;25(Suppl 2):28-36.

24. Velasco Garrido M, Kristensen FB, Palmhøj Nielsen C, Busse R. Health technology assessment and health policy-making in Europe: Current status, challenges and potential. Brussels, Belgium: European Observatory on Health Systems and Policies; 2008.

25. Wyatt JC, Liu JL. Basic concepts in medical informatics. $J$ Epidemiol Community Health. 2002;56:808-812. 